\title{
Pregnancies past the estimated date of confinement: labour and delivery outcome
}

M. Al-Taani ${ }^{1}$

$$
\begin{aligned}
& \text { الأحمال الممتلَّة: نتائج المخاض والولادة } \\
& \text { محمد الطعاني }
\end{aligned}
$$

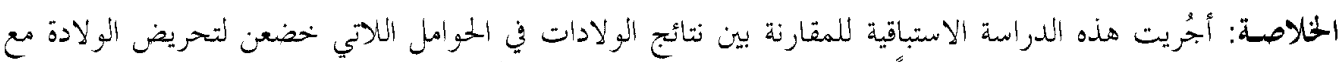

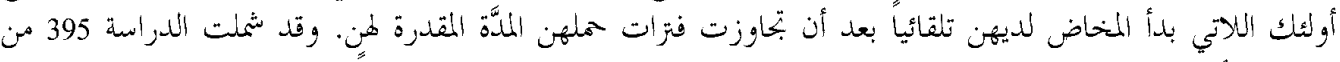

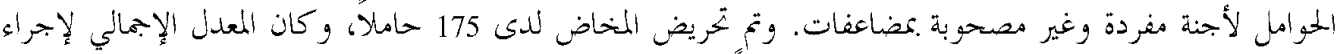

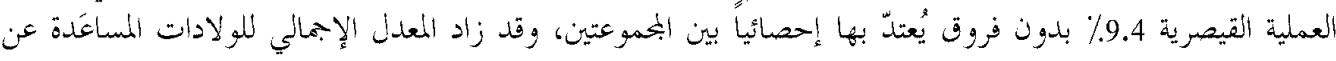

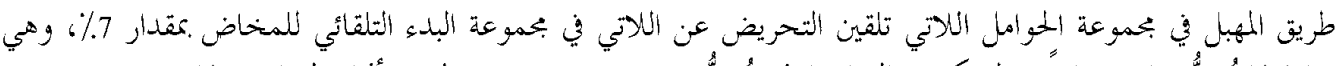

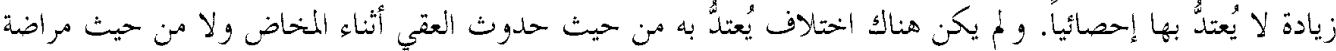

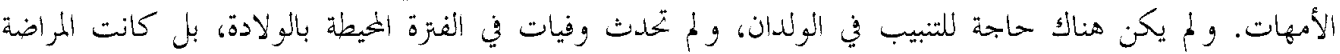

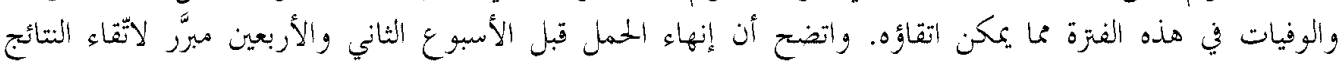

$$
\begin{aligned}
& \text { الضائرة. }
\end{aligned}
$$

ABSTRACT To compare labour and delivery outcomes in women undergoing induction and those having spontaneous onset for pregnancies past the estimated date of delivery, a prospective study of 395 singleton, uncomplicated pregnancies was performed. Labour was induced in 175 women. Overall caesarean section rate was $9.4 \%$, with no significant difference between the 2 groups. Overall rate of assisted vaginal deliveries was $7 \%$, higher in the induction group than the spontaneous onset group but the difference was not significant. There was no significant difference in occurrence of intrapartum meconium, nor for maternal morbidity. No neonate needed intubation. No perinatal deaths occurred. Perinatal mortality and morbidity are preventable, and induction of labour before 42 weeks is justifiable to prevent adverse outcomes.

\section{Grossesses prolongées : issue du travail et de l'accouchement}

RESUME Une étude prospective de 395 grossesses uniques sans complications a été réalisée afin de comparer l'issue du travail et de l'accouchement chez des femmes pour lesquelles le travail a été déclenché et chez d'autres ayant eu un accouchement spontané pour les grossesses dont le terme est dépassé. Le travail a été déclenché chez 175 femmes. Le taux global de césariennes était de 9,4\%, sans différence statistiquement significative entre les deux groupes. Le taux global d'accouchements par voie basse assistés était de $7 \%$; il était plus élevé dans le groupe de l'accouchement déclenché que dans le groupe de l'accouchement spontané, mais la différence n'était pas statistiquement significative. II n'y avait aucune différence significative pour la survenue d'une émission de méconium pendant le travail, et il n'y en avait pas non plus pour la morbidité maternelle. Aucun nouveau-né n'a eu besoin d'une intubation. II n'y a eu aucun décès périnatal. La mortalité et la morbidité périnatales sont évitables, et une interruption de grossesse avant 42 semaines est justifiable pour éviter les issues défavorables.

Department of Obstetrics and Gynaecology, Queen Alia Military Hospital, Amman, Jordan. Received: 09/10/02; accepted: 26/02/03

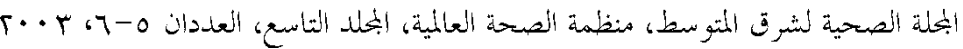




\section{Introduction}

Fetal loss in pregnancies that have passed the estimated date of confinement is a stressful experience for woman and physician alike. In prolonged pregnancies, there is a significantly greater chance of highrisk conditions developing, leading to a rise in perinatal morbidity and mortality. The presumed pathogenesis of the complications associated with postdate pregnancies is related to progressive uteroplacental insufficiency, a condition, which leads to oligohydramnios, meconium aspiration, fetal asphyxia or dysmaturity, and in severe cases fetal central nervous system damage and even death $[1,2]$. Furthermore, several studies have recognized the association between macrosomia and adverse maternal and fetal outcome, with advancing gestational age being the only contributing factor to increased morbidity and mortality [3-6].

This study was undertaken to explore the preventability of the high incidence of perinatal mortality and morbidity associated with advancing gestational age beyond term. Labour and delivery outcomes were compared for pregnancies which had passed the estimated date of confinement in women undergoing labour induction and those having spontaneous onset of labour. Pregnancies become at risk at the end of the 41 st week of amenorrhoea $[7,8]$.

\section{Methods}

Six hundred and forty-four (644) pregnant women who had passed the estimated date of confinement were admitted for delivery at Queen Alia Military Hospital, Amman, between 1 January 2001 and 31 July 2002. Of these, 249 pregnancies were excluded because of nonvertex presentation (87), associated medical or obstetric problems (31) and late antenatal booking (131). The final study population comprised 395 uncomplicated singleton pregnancies. Of these, 220 were admitted having spontaneous onset of labour (defined as the presence of painful, regular uterine contractions at least once every 5 minutes associated with at least $80 \%$ cervical effacement, with or without spontaneous rupture of membranes). The remaining 175 pregnancies were admitted from the outpatient clinic for induction of labour.

Upon admission, estimated date of confinement was assessed based on regular and good menstrual histories and early antenatal booking, where early dating examination in early gestation was calculated from the last menstrual period. This was confirmed by sonograms obtained in the first and second trimester, but before 20 weeks gestational age. Full physical and pelvic examination was performed for all the study population. Nonstress tests and liquor evaluation on sonogram were performed for all pregnancies in the induction group. Intravenous access and baseline laboratory tests were obtained.

Women admitted for induction (defined as the initiation of labour in woman with intact membranes and having no regular uterine contractions, but modified Bishop score $\leq 6$ ) had cervical priming, which was done by administering dinoprostone $3 \mathrm{mg}$ vaginal pessaries inserted in the posterior vaginal fornix. This was repeated after 6 hours if indications of onset of labour had not been detected.

For both groups, amniotomy was performed within 1-2 hours of labour diagnosis (or as soon as clinically feasible) unless membranes were spontaneously ruptured. Labour progress was monitored by pelvic examination every 2 hours. If labour abnormalities, as defined by Friedman's criteria [9], were detected, oxytocin augmentation was started and administered in the manner 
outlined by O'Driscoll and Meagher [10]. This was stopped in cases of uterine hyperstimulation or changes suggestive of fetal hypoxia. Continuous fetal heart rate monitoring during labour was performed in each woman. Fetal distress was defined as the occurrence of a fetal heart rate abnormality that necessitated termination of labour and immediate delivery, either by assisted vaginal or abdominal delivery. The presence of meconium was noted either at the time of amniotomy or subsequently during labour. Every infant had immediate suctioning of the oropharynx at the time of delivery.

The Student $t$-test was used for analysis of continuous data, while for categorical data the Fisher exact test or chi-squared test was used where appropriate; $P<0.05$ was considered significant.

\section{Results}

Between January 1, 2001 and July 31, 2002, 5859 deliveries were performed at Queen Alia Military Hospital. The caesarean section rate was $11.9 \%$, while the rate of assisted vaginal deliveries was $2.9 \%$. There were 644 (11\%) deliveries which had passed the estimated date of confinement, and 395 (6.7\%) uncomplicated singleton pregnancies met the criteria for inclusion in this study.

The two groups (spontaneous labour and induced labour) were comparable for age, parity and gestational age as shown in Table 1 , revealing no statistically significant differences. Upon admission, nonstress test results and liquor evaluation on sonogram indicated a normally grown, uncompromised fetus.

Table 2 shows the labour and delivery outcomes. There were no statistically significant differences in complication of labour between the groups. Incidence of labour augmentation using oxytocin was higher in the induction of labour group, but there was no significant difference when compared with the spontaneous onset group. There was also no statistically significant difference between groups for mode of delivery, but the incidence of assisted vaginal delivery was higher in the labour induction group. Analysing the indications for abdominal delivery, fetal distress had the highest rate for both groups, but comparison showed no statistically sig-

\begin{tabular}{|c|c|c|c|}
\hline $\begin{array}{l}\text { Demographic } \\
\text { characteristics }\end{array}$ & $\begin{array}{l}\text { Spontaneous labour } \\
(n=220)\end{array}$ & $\begin{array}{l}\text { Induced labour } \\
\quad(n=175)\end{array}$ & Significance \\
\hline Maternal age $\pm s$ (years) & $28.6 \pm 6.1$ & $28.1 \pm 6.4$ & 0.89 \\
\hline Gestational age $\pm s$ (days) & $291 \pm 2.0$ & $292 \pm 3.0$ & 0.61 \\
\hline \multicolumn{4}{|l|}{ Parity } \\
\hline $0[$ No. $(\%)]$ & $51(23.2)$ & $41(23.4)$ & 0.94 \\
\hline $1-3[$ No. $(\%)]$ & $98(44.5)$ & $79(45.1)$ & 0.89 \\
\hline$>4[$ No. $(\%)]$ & $71(32.3)$ & $55(31.4)$ & 0.81 \\
\hline
\end{tabular}

$\mathrm{s}=$ standard deviation.

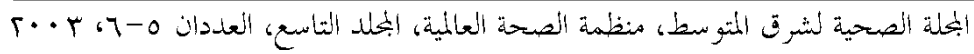




\begin{tabular}{lrrrrr}
\hline Table 2 Labour and delivery outcome according to labour type \\
\hline Outcome measure & $\begin{array}{r}\text { Spontaneous labour } \\
(\boldsymbol{n}=\mathbf{2 2 0})\end{array}$ & $\begin{array}{c}\text { Induced labour } \\
\text { ( } \boldsymbol{n = 1 7 5 )} \\
\text { No. }\end{array}$ & $\begin{array}{l}\text { No. } \\
\text { \% }\end{array}$ & Significance \\
\hline Augmentation & 137 & 62.3 & 121 & 68.6 & 0.68 \\
Intrapartum fever & 5 & 2.3 & 8 & 4.6 & 0.52 \\
Antepartum bleeding & 5 & 2.3 & 7 & 4.0 & 0.47 \\
Chorioamnionitis & 3 & 1.4 & 5 & 2.9 & 0.83 \\
Transfusion & 2 & 0.9 & 3 & 1.7 & 0.75 \\
Shoulder dystocia & 1 & 0.5 & 3 & 1.7 & 0.44 \\
Delivery & & & & & \\
$\quad$ Spontaneous vaginal & 187 & 85.0 & 143 & 81.7 & 0.37 \\
Vacuum & 9 & 4.1 & 11 & 6.3 & 0.53 \\
Forceps & 3 & 1.4 & 5 & 2.9 & 0.65 \\
Abdominal because of: & 21 & 9.5 & 16 & 9.1 & 0.88 \\
Fetal distress & 11 & 5.0 & 6 & 3.4 & 0.63 \\
Abruptio placenta & 1 & 0.5 & 2 & 1.1 & 0.51 \\
Cord prolapse & 2 & 0.9 & 0 & - & 0.76 \\
Dilatation arrest & 3 & 1.4 & 3 & 1.7 & 0.81 \\
Arrest of descent & 4 & 1.8 & 4 & 2.3 & 0.79 \\
\hline
\end{tabular}

nificant difference. Comparison for maternal morbidity between groups showed no statistically significant difference.

Fetal and neonatal outcome as shown in Table 3 revealed no statistically significant differences in outcome measures between the groups. No neonate needed intubation. No prenatal deaths occurred. All mothers and babies were discharged in good condition.

\section{Discussion}

It is common for pregnancy to pass the estimated date of confinement and this presents a difficult problem for the physician, who must decide between facing the problems of unfavourable cervix at induction and those of postmaturity complications if it is decided to let the pregnancy continue. Problems of the second option become ev- ident when the aging placenta cannot keep pace with the demands of the fetus, leading to a chronically or acutely compromised fetus.

Several studies have shown that fetal complications (macrosomia, distress, and meconium aspiration) significantly increase as pregnancy continues postterm [11-13]. Therefore, induction of labour is undertaken when the risks of labour and delivery to both mother and fetus are less than the risks of letting the pregnancy continue and the benefits of success outweigh the disadvantages of failure.

This study revealed no significant differences in operative deliveries, either vaginal or abdominal, and in the incidence of fetal distress between the groups. This differs from the results of James et al. who recommended a policy of induction at 291 days gestation in uncompromised pregnan- 


\begin{tabular}{|c|c|c|c|c|c|}
\hline \multirow[t]{2}{*}{ Outcome measure } & \multicolumn{2}{|c|}{$\begin{array}{l}\text { Spontaneous labour } \\
\qquad(n=220)^{\mathrm{a}}\end{array}$} & \multicolumn{2}{|c|}{$\begin{array}{l}\text { Induced labour } \\
\qquad(n=175)^{a}\end{array}$} & \multirow[t]{2}{*}{ Significance } \\
\hline & No. & $\%$ & No. & $\%$ & \\
\hline Intrapartum meconium & 24 & 10.9 & 18 & 10.3 & 0.88 \\
\hline 5-minute Apgar score $<7$ & 7 & 3.2 & 8 & 4.6 & 0.77 \\
\hline Meconium aspiration & 4 & 1.8 & 3 & 1.7 & 0.63 \\
\hline Hyperbilirubinaemia & 19 & 8.6 & 11 & 6.3 & 0.90 \\
\hline Cephalhaematoma & 2 & 0.9 & 3 & 1.7 & 0.76 \\
\hline Seizures & 3 & 1.4 & 2 & 1.1 & 0.71 \\
\hline $\begin{array}{l}\text { Admission to neonatal } \\
\text { intensive care unit }>24 \\
\text { hours }\end{array}$ & 16 & 7.3 & 11 & 6.3 & 0.83 \\
\hline Perinatal death & 0 & - & 0 & - & 0.69 \\
\hline
\end{tabular}

${ }^{a}$ The mean birth weight \pm standard deviation for the spontaneous labour group was $3724 \pm 488 \mathrm{~g}$; the mean birth weight \pm standard deviation for the induced labour group was $3713 \pm 434 \mathrm{~g}$. The difference was not statistically significant.

cy [14]. Kaplan et al. reported reduced perinatal morbidity using prostaglandin induction of labour to ripen a stubborn cervix [15]. In our study, cervical priming was carried out using intravaginal pessaries of dinoprostone $3 \mathrm{mg}$, a safe and efficacious method giving excellent results for induction. This is in agreement with the results of Prysak and Castronova [16]. Herabutya et al. reported an increased incidence of neonatal intubation in postdate pregnancies managed expectantly and concluded that there was no particular advantage to letting pregnancy go beyond 42 weeks, especially if prostaglandin is available [17]. We had no perinatal deaths and no significant differ- ences in maternal morbidity between groups was observed.

In summary, the risk to the fetus and mother increases as pregnancy continues postterm. Fetal and maternal morbidity are preventable by taking a prompt decision to induce labour in uncomplicated pregnancies that have passed the estimated date of confinement. Therefore, measures to deliver the baby between 41 and 42 weeks are justifiable to prevent adverse outcomes. Intervention before 42 weeks gestation when the fetus is not in jeopardy and is capable of withstanding the stress of labour should be encouraged.

\section{References}

1. Dyson DC. Fetal surveillance vs. labour induction at 42 weeks in postterm gestation. Journal of reproductive medicine, 1988, 33:262-70.
2. Cunningham FG et al., eds. Williams obstetrics, 20th ed. Stamford, Connecticut, Appleton and Lange, 1997:827-37.

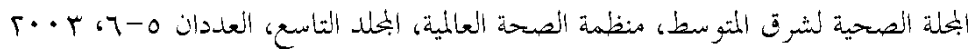


3. Chervenak JL et al. Macrosomia in the postdate pregnancy: is routine ultrasonographic indicated? American journal of obstetrics and gynecology, 1989, 161:753-6.

4. Pollak RN, Hauer-Pollak G, Divon MY. Macrosomia in postdates pregnancies: the accuracy of routine ultrasonographic screening. American journal of obstetrics and gynecology, 1992, 167:7-11.

5. Saito $\mathrm{M}$ et al. Time of ovulation and prolonged pregnancy. American journal of obstetrics and gynecology, 1972, 112: 31-8.

6. Eden RD, Steifert L, Winegar A. Perinatal characteristics of uncomplicated postdate pregnancies. Obstetrics and gynecology, 1987, 53:721.

7. Guidetti DA, Divon MV, Langer O. Postdate fetal surveillance: Is 41 weeks too early? American journal of obstetrics and gynecology, 1989, 161:91-3.

8. Boisselier $P$, Guettier $X$. Le terme depasse. Revue de la literature. [Prolonged pregnancy. Review of the literature.] Journal de gynécologie, obstétrique et biologie de la reproduction, 1995, 24(7):739-46.

9. Friedman EA. The labour curve. Clinics in perinatology, 1981, 8:15-25.

10. O'Driscoll K, Meagher D. Active management of labour: the Dublin experience. 2nd ed. London, Ballière Tindal, 1986.
11. Arias F. Predictability of complications associated with prolongation of pregnancy. Obstetrics and gynecology, 1987, 70:101-6.

12. Divon MY et al. Fetal and neonatal mortality in the postterm pregnancy: the impact of gestational age and fetal growth restriction. American journal of obstetrics and gynecology, 1998, 178:726-31.

13. Votta RA, Cibils LA. Active management of prolonged pregnancy. American journal of obstetrics and gynecology, 1993, 168(2):557-63.

14. James $C$ et al. Management of prolonged pregnancy: a randomized trial of induction of labour and antepartum foetal monitoring. National medical journal of India, 2001, 14(5):270-3.

15. Kaplan B et al. The outcome of post-term pregnancy. A comparative study. Journal of perinatal medicine, 1995, 23(3):1839.

16. Prysak M, Castronova FC. Elective induction versus spontaneous labor: a case-control analysis of safety and efficacy. Obstetrics and gynecology, 1998, 92:47-52.

17. Herabutya et al. Prolonged pregnancy: the management dilemma. International journal of gynaecology and obstetrics, 1992, 37(4):253-8. 